\title{
Zakon o davčnem postopku v okviru odprave administrativnih ovir - med cilji in prakso
}

UDK: 336.225(045)

Polona Kovač

Fakultetaza upravo Univerze v Ljubljani

polona.kovac@fu.uni-lj.si

\section{IZVLEČEK}

Zakon o davčnem postopku je ključni predpis za urejanje razmerij med udeleženci postopkov pri pobiranju davkov. Zato je bil v zadnjih letih že večkrat bolj ali manj korenito spremenjen, med drugim v sklopu vladnega programa odprave administrativnih ovir (OAO). Postopki se skušajo poenostaviti, tako za zavezance kot za davčni organ. Avtorica v prispevku obravnava nekaj izbranih institutov, ki naj bi bili uvedeni $s$ tem ciljem, denimo odmera dohodnine $z$ informativnim izračunom, navadno vročanje, zavezujoča informacija itd. Prek statističnih podatkov o pogostnosti uporabe teh (novih) institutov v letih 2006, 2007 in 2008 avtorica preverja, ali oziroma do katere mere zastavljeni cilji sprememb regulacije davčnega postopka v praksi dosegajo cilj. Ugotavlja, da kljub nekaj izjemam večina obravnavanih institutov res pomeni realizacijo programa OAO.

Ključne besede: davčni postopek, zakon, odprava administrativnih ovir.

JEL: H2O, K40, D73

\section{Presek davčnega postopka in odprave admini- strativnih ovir}

Namen prispevka je obravnavati, ali in v katerih elementih je sprejem oziroma noveliranje zakonov o davčnem postopku v sklopu programa odprave administrativnih ovir $(\mathrm{OAO}) \vee$ zadnjih nekaj letih $\vee$ praksi doseglo zastavljeni cilj. $\vee$ ta namen smo izbrali nekaj institutov, ki so $\vee$ več gradivih (predvsem $\vee$ predlogu ZDavP-2 ${ }^{\prime}$

1 Dostopno na spletnih straneh Slovenija jutri, EVA: 2006-1611-0024 (gradivo za prvo obravnavo, jesen 2006). Tudi v Poročevalec Državnega zbora RS, št. 99/06 (20. 9. 2006). 
Polona Kovač

Zakon o davčnem postopku v okviru odprave administrativnih ovir - med cilji in prakso

in $\vee$ dokumentih o Strategiji razvoja Slovenije) opredeljeni kot OAO, nato pa primerjali podatke Davčne uprave RS (DURS) o realizaciji teh institutov po statističnih podatkih. ${ }^{2}$

Davčni postopek je posebni upravni ${ }^{3}$ postopek, $v$ katerem se zagotavlja pobiranje davkov, torej obračun oziroma odmera in plačilo oziroma vračilo davka, nadzor nad davčnimi obveznostmi, izterjava upravnih denarnih obveznosti zavezanih strank ter mednarodno sodelovanje $v$ davčnih zadevah (Jerovšek in Kovač, 2008, splošno Kopp \& Ramsauer, 2003). Davčni postopek je urejen z več predpisi. Nekaj procesnih določb vsebujejo sami predpisi o obdavčitvi za posamezne vrste davkov, pretežno se uporablja Zakon o davčnem postopku (tak zakon imamo v Sloveniji od leta 1996, več Šinkovec, 2002, sedaj velja ZDavP-2 ${ }^{4}$ ), podrejeno zakona, ki urejata davčno in carinsko službo, delno Zakon o inšpekcijskem nadzoru (ZIN), Zakon o splošnem upravnem postopku $\left(Z^{\prime} P^{\mathbf{5}}\right.$ ) in izvršilni akti navedenih predpisov (o subsidiarnosti splošno Androjna in Kerševan, 2006). Za OAO na strani zavezancev, davčnega organa in nenazadnje drugih sodelujočih subjektov $\vee$ postopkih (npr. bank, delodajalcev, registrskih institucij, ki posredujejo podatke) je ključen predvsem zakon o davčnem postopku, delno pa tudi ZIN in ZUP. Slednja dva sta (bila) prav tako večkrat predmet novelacij $v$ kontekstu $O A O .^{\boldsymbol{6}} \mathrm{A}$ vse to $\mathrm{k} O A O \vee$ davčnih

2 Večina podatkov je zbranih iz letnih poročil o delu DURS, ki so objavljeni na spletnih straneh. Pri zbiranju podatkov in njihovi obdelavi so poleg avtorice tega prispevka v okviru predmeta Raziskovalni seminar sodelovale štiri podiplomske študentke Fakultete za upravo. $\mathrm{Na}$ tem mestu se zahvaljujem DURS, zlasti A. Kovač Arh in P. Jenku iz Pravne službe Generalnega davčnega urada DURS za sodelovanje pri zbiranju tistih podatkov, ki (še) niso javno dostopni na internetu, pa smo jih ocenili kot relevantne za obravnavo $v$ prispevku navedenih vprašanj.

3 Davčni organi vodijo predvsem upravne postopke, ki pa so se jim v okviru pristojnosti davčne inšpekcije leta 2005 pridružili še hitri postopki o prekršku, če kršitev davčnih predpisov pomeni pravni stan prekrška, leta 2007 pa so se na podlagi ZDavP-2 uvedle tudi davčne preiskave kot sui generis postopki (predupravni oziroma predprekrškovni). Upravni postopek je presečišče, ki naj zagotovi, da sta javni in zasebni interes uravnotežena, sorazmerna (o tem Komentar Ustave RS, 2002). Če je narava pravice, obveznosti ali pravne koristi opredeljena kot upravna zadeva, mora upravni postopek zagotoviti, da javni interes ni zaščiten čezmerno in hkrati da zasebni interes ni nadrejen javnemu (načelo varstva pravic strank in javne koristi, 7. člen ZUP).

4 Objavljen v Ur. I. RS št. 117/06, 24/08-ZDDKIS, 125/08-ZDavP-2A, 20/09-ZDoh-2D.

5 Ur. I. RS, št. 80/99, 70/00-ZUP-A, 52/02-ZUP-B, 73/04-ZUP-C, 119/05-ZUP-D, 24/06-UPB2, 105/06-ZUS-1, 126/07-ZUP-E, 65/08-ZUP-F.

$6 \mathrm{Npr}$. izmenjava podatkov kot breme organov, 66. in 139. člen ZUP (Androjna in Kerševan, 2006, str. 303), odprava strokovnega izpita iz upravnega postopka, 31. člen ZUP, preventivni ukrep opozorila, 28. člen ZIN (Pirnat et al., 2004), sprejem vlog izven davčnih uradov in sobotne uradne ure na davčnih uradih (po Uredbi o upravnem poslovanju, gl. uvodna pojasnila $v$ Kovač et al., 2008). Sobotne uradne ure so bile uvedene leta 2007, pri čemer je davčne urade $\checkmark$ tem času obiskalo le okoli 0,9 stranke na 1 uslužbenca v letu 2007, a kljub enakim podatkom v letu 2008 obvezne uradne ure niso bile odpravljene vse do leta 2009. 
postopkih pripomore zaradi posebnosti in relativno celostne specifične ureditve davčnega postopka (Šinkovec, 2002) prejkone minorno, zato se v nadaljevanju osredotočamo na spreminjanje zakonov o davčnem postopku.

Program OAO se v slovenski javni upravi izvaja že več let (predvsem od leta 2001, ko je bila ustanovljena vladna komisija za OAO, o razvoju programa in nosilcih Josevski, 2008). Cilji in aktivnosti programa se pogosto kažejo tudi v normativnih ukrepih. Pri tem Slovenija praviloma sledi dobrim praksam iz tujine (npr. samoprijava in zavezujoča informacija, več v predlogu ZDavP-2, 2006, in Jerovšek et al., 2008). Na področju davčnega prava se izvaja spremembe, ki so materialnopravne (npr. uvajanje novih olajšav, odprava določenih davkov), kot predvsem procesne, saj se lahko olajša zlasti način uveljavljanja pravic, pravnih koristi in obveznosti zavezancev za davek glede poenostavitev za vse udeležence postopkov (prim. Jerovšek, 2005, Kovač, 2006). Na ta način se med drugim doseže večjo stopnjo prilagodljivosti zavezancev kot nosilcev gospodarske dejavnosti razmeram na trgu, torej njihovo večjo konkurenčno sposobnost. Med novostmi poenostavitve postopkov, kar je bil eden ključnih ciljev OAO pri pripravi sprememb zakonov o davčnem postopku v letih 2004-2009, so nekatere določbe zakonov, ki so očitno zavezancem v korist; hkrati je delo ponekod olajšano tudi davčnim organom, čeprav morda zavezance bremeni (Jerovšek, 2005a, Kovač, 2007). Cilj OAO je v čim večji meri razbremeniti davčni organ in fizične oziroma pravne osebe kot zavezance $z$ administrativnimi opravili, ki povzročajo izgubo časa in dodatne stroške, brez dodane vrednosti, saj gre za opravila, ki se podvajajo ali so nesmiselna za cilj davčnega postopka, tj. pobiranje davkov. Temelj davčne reforme kot celovitejšega sklopa ukrepov znotraj in prek OAO, ki je bila zastavljena predvsem v letih 2006 in 2007, je tako spodbujanje konkurenčnosti nacionalnega gospodarstva ter enovitost sistema $\vee$ razmerju do zavezancev in družbe kot celote. Davčna reforma skuša udejaniti cilje vladnih reform $v$ smislu spodbujanja podjetništva in konkurenčnosti Slovenije, kot izhajajo iz Lizbonske strategije, Strategije razvoja Slovenije in Programa ukrepov Vlade Republike Slovenije za spodbujanje podjetništva in konkurenčnosti za obdobje 2007-2013 (Vlada, 2008). Zakon o davčnem postopku je bil zato leta 1996 sploh oblikovan in sprejet ${ }^{7}$ (prej smo imeli $\vee$ Sloveniji le nekaj procesnih določb $\vee$ materialnih zakonih in takojšnjo rabo ZUP) in nadalje večkrat bolj ali manj korenito spreminjan. Tako beležimo več zakonov oziroma novel, ki so podlage za opredelitev več obdobij regulacije davčnega postopka $\vee$ Sloveniji, kot izhaja iz tabele 1.

7 Ur. I. RS, št. 18/96, 78/96 SkI.US: U-I-376/96, 87/97, 35/98 OdI.US: U-I-376/96-9, 82/98, 91/98, 1/99-ZNIDC, 108/99, 37/01 Odl.US: U-I-18/98-20, 97/01, 31/03 Odl.US: U-I-72/00-15, 33/03 Skl.US: U-I-108/99-14, 105/03 Odl.US: U-I-252/00-12, 16/04 Odl.US: U-I-233/01-14, 42/04 Odl.US: U-I-329/02-7. 
Polona Kovač

Zakon o davčnem postopku v okviru odprave administrativnih ovir - med cilji in prakso

\section{Tabela 1: Obdobja in (novele) zakoni(ov) o davčnem postopku}

\begin{tabular}{|c|c|c|c|}
\hline št. & Obdobje & Pravna podlaga & $\begin{array}{l}\text { Čas veljave oziroma upo- } \\
\text { rabe }^{\boldsymbol{8}}\end{array}$ \\
\hline 1 & $\begin{array}{l}\text { Ureditev brez samostojnega zako- } \\
\text { na o davčnem postopku }\end{array}$ & $\begin{array}{l}\text { Področni zakoni } \\
\text { obdavčitvi in ZUP }\end{array}$ & Do 31. 12. 1996 \\
\hline 2 & $\begin{array}{l}\text { Ureditev } \mathrm{s} \text { (prvim slovenskim) } \\
\text { samostojnim zakonom o davčnem } \\
\text { postopku }\end{array}$ & ZDavP & $\begin{array}{l}\text { 1. 1. } 1997 \text { - maj 2004/ 1. } 1 . \\
2005\end{array}$ \\
\hline 3 & $\begin{array}{l}\text { Ureditev po polnopravni včlanitvi } \\
\text { RS } \vee \text { EU - nov (drugi slovenski) } \\
\text { zakon }\end{array}$ & $\mathrm{ZDavP}-1^{10}$ & $\begin{array}{l}\text { 1. 1. } 2005-31.12 .2006 \\
\text { (del že od maja 2004) }\end{array}$ \\
\hline 4 & $\begin{array}{l}\text { Ureditev po ukrepih davčne } \\
\text { reforme-novelacija }\end{array}$ & ZDavP-1B & 1. 1. $2006-31.12 .2006$ \\
\hline 5 & $\begin{array}{l}\text { Celovita ureditev davčnega posto- } \\
\text { pka } \vee \text { okviru davčne reforme - } \\
\text { novi (tretji slovenski) zakon }\end{array}$ & ZDavP-2 & $\begin{array}{l}\text { Velja od novembra 2006, } \\
\text { uporablja se od 1. 1. } 2007 \text { - }\end{array}$ \\
\hline 6 & $\begin{array}{l}\text { Noveliranje } \vee \text { okviru gospodarske } \\
\text { krize }\end{array}$ & $\begin{array}{l}\text { ZDavP-2A } \\
\text { ZDoh-2D }\end{array}$ & $\begin{array}{l}\text { 31. 12. } 2008 \\
\text { Velja od 14. 3. 2009, upora- } \\
\text { blja se od januarja 2009. }\end{array}$ \\
\hline
\end{tabular}

V nadaljevanju obravnavamo izbrane institute davčnega postopka, ki naj bi bili del programa OAO, po absolutnih podatkih na letno osnovo in trendih uporabe zlasti za leta:

8 Po ZDavP-2 se neveljavni zakoni še uporabljajo, 418. člen ZDavP-2. ZDavP-2 se ne uporablja $v$ zadevah, glede katerih je bilo ob začetku uporabe ZDavP-2, tj. 1. 1. 2007, vloženo redno ali izredno pravno sredstvo $v$ upravnem postopku oziroma upravni spor, tedaj se zadeva konča po ZDavP-1 (UPB2); preko tega pa lahko še celo po prejšnjih zakonih glede na njihove prehodne in končne določbe, če se bo končal upravni postopek oziroma upravni spor $s$ spremembo ali razveljavitvijo davčne odločbe. Toda zaradi enakega varstva pravic (22. člen Ustave, gl. Šturm et al., 2002) se v obnovljenem postopku glede materialnih predpisov uporabi predpis za tisto davčno obdobje, na katero se davčna odločba nanaša (razen če ima ZDavP-2 za zavezanca ugodnejšo materialno določbo, npr. nastop zastaranja, po Jerovšek et al., 2008).

9 Pri tem kaže opozoriti, da je davčni postopek edini med približno 400-500 posebnimi upravnimi postopki, kolikor jih pozna slovenski pravni red, ki je determiniran s posebnim procesnim zakonom, kajti drugi postopki so procesno delno urejeni s specialnimi določbami postopka v materialnih zakonih in z ZUP (Androjna in Kerševan, 2006, Jerovšek in Kovač, 2008).

10 Ur. I. RS, št. 54/04, 57/04-ZDS-1, 109/04 Odl. US: U-I-356/02-14, 128/04 Odl. US U-I-166/0312, 139/04, 56/05 Skl. US U-I-159/05-4, 96/05-ZRTVS-1, 100/05 Odl. US U-I-159/05-14, 109/05, 21/06 Odl. US: U-I-32/04-10, 21/06-UPB2.

11 Po ZDoh-2D velja, da lahko zavezanec ne glede na 54. člen ZDavP-2 že za leto 2008 uveljavlja znižanje določene davčne osnove $s$ predložitvijo popravka obračuna najpozneje $v 30$ dneh od uveljavitve novele (torej zakon učinkuje $v$ korist zavezancev glede obdobja in postopkovno za nazaj). 
- 2006 uveljavitev ZDavP-1B,

- 2007 in 2008 - uporaba ZDavP-2, ki je (večinoma) prevzel institute ZDavP-1B glede OAO in dodal nove.

\section{Pregled rabe izbranih institutov ZDavP-2 v praksi}

\subsection{Izbor obravnavanih institutov}

$\checkmark$ zgoraj opisanem smislu $v$ tem prispevku preučujemo le nekatere institute zakonov, pri čemer je treba poudariti, da bi celovita analiza regulacije davčnega postopka in OAO morala vključevati različna pravila, čeprav na prvi pogled ne stremijo k OAO, saj celota norm skupaj večplastno učinkuje na končni izid ne/realizacije reformnih ciljev (Pirnat et al., 2004). Tako med institute ZDavP in hkrati program OAO ne uvrščamo npr. temeljnih načel davčnega postopka, čeprav je nekaj celo po evropski sodni praksi takih (npr. načelo sorazmernosti, gl. Šinkovec, 2002, Kovač, 2006a), ki dokaj neposredno pripomorejo k uveljavitvi ciljev OAO $\vee$ posamičnih postopkih (nekatera načela so neposredno podlaga za določene institute, npr. načelo gotovosti za zavezujočo informacijo).

OAO regulacija davčnega postopka sploh od leta 2006 dalje zelo upošteva, zlasti ZDavP-2 je nedvomno zakon, ki vsebuje večje število norm, katerih cilj je OAO oziroma poenostavitve (po Predlogu ZDavP-2, 2006, str. 2-14). Proces OAO $\vee$ ZDavP se sicer uresničuje korakoma; postopno se z novimi zakoni in novelami zakona uvaja čedalje več institutov OAO (gl. tabelo 2). Predstavljeni podatki so tako relevantni kot študija primerov. Zaradi izrecnih navedb predlagatelja zakona ${ }^{\mathbf{1 2}}$ o OAO in glede na dostopne podatke DURS smo $\vee$ ožji izbor vključili sedem institutov (vrstni red po naraščajoči številki člena ZDavP-2):

12 Po Predlogu ZDavP-2, 2006, denimo str. 2 in 14 za odmero dohodnine, str. 9 in 185 za odlog plačila davka, str. 182 glede navadnega vročanja. Obširneje v Jerovšek et al., 2008, pri komentarjih k posameznim določbam, glede predizpolnjene napovedi prim. Klun, 2009 (npr. prva država s predizpolnjeno napovedjo je bila Danska leta 1990). 
Polona Kovač

Zakon o davčnem postopku v okviru odprave

administrativnih ovir - med cilji in prakso

Tabela 2: Pregled obravnavanih institutov davčnega postopka v sklopu OAO

\begin{tabular}{|c|c|c|c|}
\hline št. & Institut & Pravne podlage & $\begin{array}{l}\text { Čas veljave } \\
(2006-2008)\end{array}$ \\
\hline 1 & Zavezujoča informacija & 14. člen ZDavP-2 & 2007 in 2008 \\
\hline 2 & Samoprijava & $\begin{array}{l}\text { 390.a, 390.b člen ZDavP-1 } \\
\text { 55. in 63., 396., 399. idr. Členi ZDavP-2 }\end{array}$ & $\begin{array}{l}2006 \\
2007 \text { in } 2008\end{array}$ \\
\hline 3 & (Navadno) Vročanje & 85. člen ZDavP-2 & 2007 in 2008 \\
\hline 4 & $\begin{array}{l}\text { Odpis, odlog in } \\
\text { obročno plačilo davka }\end{array}$ & $\begin{array}{l}\text { 36. in 37. člen ZDavP-1 } \\
\text { 101. in 102. člen ZDavP-2 (novo pa } \\
\text { 103. (posebni primeri) in } \\
\text { 105. člen (odpis po višini do } 1 \text { EUR)) }\end{array}$ & $\begin{array}{l}2006 \\
2007 \text { in } 2008\end{array}$ \\
\hline 5 & Davčna preiskava & 131. člen ZDavP-2 & 2007 in 2008 \\
\hline 6 & $\begin{array}{l}\text { Obvestilo o } \\
\text { neplačanem davku v } \\
\text { izvršbi }\end{array}$ & $\begin{array}{l}\text { 128. člen ZDavP-1 } \\
\text { (odpravljeno z ZDavP-2) }\end{array}$ & 2006 \\
\hline 7 & $\begin{array}{l}\text { Informativni izračun pri } \\
\text { odmeri dohodnine }\end{array}$ & $\begin{array}{l}\text { 421. člen ZDavP-2 } \\
\text { (predizpolnjena napoved za dohodnino za } \\
\text { leto 2006, torej postopki v letu 2007) } \\
\text { 267. in nadaljnji členi ZDavP-2 } \\
\text { (predhodni informativni izračun) }\end{array}$ & 2007 \\
\hline
\end{tabular}

Pri teh institutih postavljamo hipotezo, da se uporabljajo različno pogosto, vendar pa naj bi trend rabe po statističnih podatkih naraščal, če naj bi bil cilj OAO v praksi dosežen. Pri tem je ponekod upoštevan status zavezancev za davek, $v$ odvisnosti, ali gre za gospodarske subjekte (predvsem pravne osebe in fizične osebe, ki so samostojni nosilci dejavnost), saj je program OAO (na davčnem področju) prednostno usmerjen k dejavnemu poslovanju tistih zavezancev, ki so ključni za delovanje trga, torej gospodarstva.

Sicer ima ZDavP-2 (in že prej ZDavP-1) še vrsto drugih določb v zvezi z OAO. Ključnega pomena je primarnost obračuna kot načina izpolnitve davčne obveznosti (več Jerovšek in Kovač, 2008), Dalje je npr. pomembna določba 50. člena ZDavP-2 o bagatelnem znesku pod 10 evri, ki se sploh ne odmeri, postopek se tu zaključi z 
Polona Kovač

Zakon o davčnem postopku v okviru odprave administrativnih ovir - med cilji in prakso

uradnim zaznamkom, saj bi znesek davka ne dosegel povprečnine stroškov vodenja enostavnega davčnega postopka (seveda pa se obveznost prenese $v$ naslednjo obračunsko obdobje). Podobno se ne vrne preveč plačani davek brez zahtevka stranke po 97. členu ZDavP-2 ali uvede postopek izterjave po 149. členu ZDavP-2, če gre za zneske pod 10 EUR. DURS po zakonu ne izterjuje davčnih obveznosti za RTV oziroma članarine zbornicam. Določene so dodatne oblike zavarovanj, jasno je normirano razmerje med oddajo obračuna ali napovedi $v$ roku ali po roku, v postopku se praviloma uporablja kot dokazilo le listine, dokazno breme je pri cenitvi davčne osnove obrnjeno, stroški se obračunavajo po posebej opredeljenem načelu uspeha in sorazmerno, odločba se lahko izda le $\vee$ obliki štampiljke, kontrola obračunov se lahko izvede ob ugotovljenih odstopanjih z direktnim plačilom razlike, vzpostavljene so povezave med postopki (npr. kontrolni in inšpekcijski, vpliv ugotovitev inšpekcije na obnove postopkov, prim. Šinkovec, 2002), praviloma je omejeno trajanje inšpekcije na 6 mesecev, rok za pritožbo zoper inšpekcijske odločbe je podaljšan na 30 dni od vročitve, dodan je samostojni dolgovni seznam kot podlaga, da se uvede le en izvršilni postopek ob več izvršilnih naslovih, institucionalizirano je mednarodno sodelovanje $\vee$ davčnih zadevah itd. (več $v$ Jerovšek et al., 2008).

\subsection{Zavezujoča informacija}

Zavezujočo informacijo izda zavezancu glede bodoče davčne bremenitve glavni davčni oziroma carinski urad, da se zavezanec laže odloči, ali bo predvideni davek kot del stroškov pomenil preveliko breme za posel v primerjavi s pričakovanim dobičkom in torej vanj ne bo šel (Jerovšek et al., 2008). Zavezujoča informacija je bila uvedena 2007 kot izraz načela gotovosti, čeprav je postopkovno zapisana tako, da s kopico rezervnih klavzul močno omeji predvideni pozitivni učinek instituta (npr. kar 6 mesečni rok za izdajo, več Kovač, 2006). Institut naj bi bil aktualen predvsem za pravne osebe, zlasti investicije tujcev glede na vidik pravne varnosti na področju davčne zakonodaje (Predlog ZDavP-2, 2006, str. 168). V praksi se po izkušnjah DURS kaže nerazumevanje namena tega instituta, saj zavezanci neredko na podlagi 14. člena ZDavP-2 dejansko uveljavljajo informacije o že izvedenih poslih oziroma dogodkih ali pa zahtevajo splošno pojasnilo predpisa. Zavezujočo informacijo je namreč treba razumeti kot abstrakten (za še ne nastale pravne položaje) in hkrati posamičen akt (za določenega naslovnika oziroma predmet obdavčitve). 
Polona Kovač

Zakon o davčnem postopku v okviru odprave

administrativnih ovir - med cilji in prakso

Tabela 3: Podatki o zavezujočih informacijah 2007 in 2008

\begin{tabular}{|lcc|}
\hline & 2007 & 2008 \\
\hline Število prejetih zahtevkov za izdajo zavezujoče informacije & 14 & 7 \\
\hline Število izdanih zavezujočih informacij & $2^{*}$ & $3^{*}$ \\
\hline
\end{tabular}

* Od tega se je $v$ obeh letih ena informacija nanašala na davek na dodano vrednost, preostale pa na davek od dohodka pravnih oseb.

Leta 2007 so d.d. in d.o.o od 14 zahtev podale 11 zahtev., leta 2008 je bilo teh 6 od 7. V obeh letih so d.o.o. vložile $57 \%$ vseh zahtev. Zavezujoča informacija $\vee$ Sloveniji (še) ni zaživela - še zahteve, ki so vložene, niso niti procesno ustrezne, kronološki trend pogostnosti vlog je negativen. Glede na vrste davkov in status prosilcev pa drži, da so zavezujoče informacije uporabne za večje gospodarske subjekte oziroma posle, pri čemer nekateri razumejo delo davčnega organa napačno kot davčno svetovanje (verjetno zato več zahtev d.o.o. kot denimo d.d.). Glede na podatke o številu zavezancev in poslovnimi subjekti po Poslovnem registru (približno 84.000 pravnih in 78.000 fizičnih oseb) lahko zaključimo, da zavezujoča informacija ne dosega zastavljenih ciljev. Glede na to, da je npr. na Nizozemskem poslovanje prek zavezujočih informacij stvar organizacije davčnega organa in ne materia legis, lahko z veliko verjetnostjo sklepamo, da je naš zakon preveč zbirokratiziran.

\subsection{Samoprijava}

V letu 2006 je bil z ZDavP-1B uveden institut samoprijave, vsebinsko in nomotehnično (z ločitvijo na procesni in kazenski del ter določitvijo sosledja za vrnitvijo v prejšnje stanje) izboljšan z ZDavP-2. Samoprijava je dopustna za pravne in fizične osebe po izteku rokov za oddajo obračuna (in odtegljaja) in napovedi za odmero davka, pri čemer zavezanec dolgovani davek takoj tudi plača (Predlog ZDavP-2, 2006, str. 176). Ta institut naj bi združil koristi za javni interes (davek, ki sicer verjetno ne bi bil pobran) in zavezanca, ki sicer plača davek, zamudne in kazenske obresti, a je prekrškovno ekskulpiran, če poda prijavo, preden davčni organ odkrije prenizko (ali sploh ne) pobrano obveznost (prim. Jerovšek, 2005a). Samoprijava je namreč mogoča do izdaje odmerne odločbe, začetka inšpekcijskega (upravnega) ${ }^{13}$ oziroma prekrškovnega ali ka-

13 Samoprijava je po ZDavP-2 dopustna do vročitve sklepa o začetku inšpekcijskega nadzora. Prej je bil sporen trenutek začetka inšpekcijskega postopka, saj je lahko zavezanec vložil samoprijavo v letu 2006 po prejemu obvestila o nadzoru, kar je smiselnost nadzora izničilo 
Polona Kovač

Zakon o davčnem postopku v okviru odprave administrativnih ovir - med cilji in prakso

zenskega postopka zoper zavezanca. Samoprijava odraža operacionalizacijo načel materialne resnice in izpolnjevanja davčnih obveznosti (s kombinacijo sankcij po Silvani in Baer, 1997, str. 11, 25), čeprav po mnenju nekaterih posega prek kazenske odgovornosti $\vee$ ustavni privilegij zoper samoobtožbo, zaradi česar bi morali ZDavP-2 jasneje urediti (Ferlinc, 2009).

Tabela 4: število in vrednost samoprijav 2006-2008 po vrstah davkov

\begin{tabular}{|c|c|c|c|c|c|c|}
\hline \multirow[b]{2}{*}{ Vrsta davka } & \multicolumn{2}{|r|}{2006} & \multicolumn{2}{|c|}{2007} & \multicolumn{2}{|c|}{2008} \\
\hline & 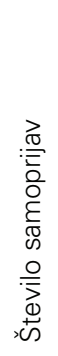 & 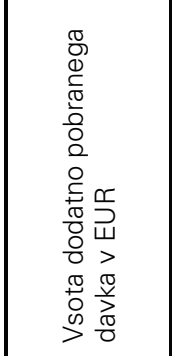 & 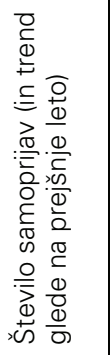 & 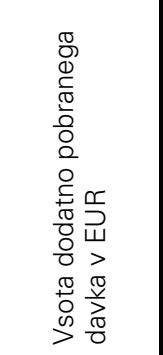 & 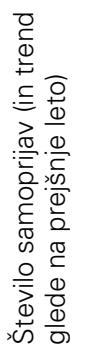 & 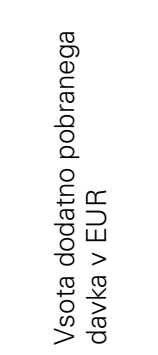 \\
\hline $\begin{array}{l}\text { Davki in prispevki od } \\
\text { dohodkov fizičnih oseb }\end{array}$ & 10 & 101,202 & $\begin{array}{c}\uparrow \\
368\end{array}$ & $1,295,468.38$ & $\begin{array}{c}\uparrow \\
426\end{array}$ & $870,372.06$ \\
\hline Dohodnina & 425 & 165,957 & $\begin{array}{c}\uparrow \\
3,188\end{array}$ & $364,478.24$ & $\stackrel{\downarrow}{1,089}$ & $163,962.85$ \\
\hline Akontacija dohodnine & 17 & 25,914 & $\begin{array}{c}\uparrow \\
794\end{array}$ & $124,637.00$ & $\begin{array}{c}\uparrow \\
1,211\end{array}$ & $176,689.31$ \\
\hline $\begin{array}{l}\text { Davek od dohodkov } \\
\text { pravnih oseb }\end{array}$ & 31 & $2,084,645$ & $\begin{array}{c}\uparrow \\
161\end{array}$ & $3,529,711,72$ & $\begin{array}{c}\downarrow \\
122\end{array}$ & $5,495,619.59$ \\
\hline DDV & 8 & 381,956 & $\begin{array}{c}\uparrow \\
103\end{array}$ & $2,094,735.79$ & $\begin{array}{c}\uparrow \\
309\end{array}$ & $1,974,054.74$ \\
\hline Druge dajatve & 0 & 0 & $\begin{array}{c}\uparrow \\
3,948\end{array}$ & $598,654.95$ & $\begin{array}{c}\downarrow \\
656\end{array}$ & $400,183.74$ \\
\hline Davek iz kapitala & 0 & 0 & 0 & 0.00 & $\begin{array}{c}\uparrow \\
5,239\end{array}$ & $918,253.60$ \\
\hline $\begin{array}{l}\text { Izvajanje mednarodnih } \\
\text { pogodb }\end{array}$ & 0 & 0 & 0 & 0.00 & $\begin{array}{l}\uparrow \\
1\end{array}$ & 488.45 \\
\hline SKUPAJ & 491 & $2,759,674$ & 8,562 & $8,007,686.44$ & 9,053 & $9,999,624.34$ \\
\hline
\end{tabular}

(prim. Jerovšek et al., 2008). V sklopu temeljnih načel ZDavP-2 davčni uradi zavezance lahko (ni pa obvezno) telefonsko oziroma z navadnim e-sporočilom obveščajo o predvidenih nadzorih, s čimer (zakonito) pospešijo prijave in zmanjšujejo potrebne inšpekcije. 


\section{Polona Kovač \\ Zakon o davčnem postopku v okviru odprave administrativnih ovir - med cilji in prakso}

Po številu samoprijav prevladuje $\vee$ letu 2006 dohodnina, leta 2007 druge dajatve (od tega predvsem članarine (3.948), nadalje davek na promet nepremičnin, davek na dediščine itd.), leta 2008 davek iz kapitala (predvsem iz naslova obresti (4.022 od 5.239)), na novo mednarodne izterjave, pri čemer je znesek pričakovano nesorazmeren s številom prijav, saj so določeni davki po naravi izdatnejši. Tako je največ donosa na podlagi samoprijav $v$ vseh letih pripisati davku od dohodka pravnih oseb s povečanjem z dobrih 2 mio EUR leta 2006 na že skoraj 5,5 mio EUR dve leti kasneje. Tako število samoprijav kot zneski pobranih dajatev iz tega naslova se $v$ letih 2006-2008 po vseh kazalnikih nedvomno povečujejo, spreminja pa se struktura le-teh. Zavezanci očitno potrebujejo čas za posvojitev zakonskih novosti, kar izkazuje denimo izreden porast števila samoprijav iz leta 2006 (nekaj manj kot 500) v 2007 (že kar prek 8.500), podobno npr. ugotovimo s parcialnim področjem akontacij dohodnin pri s.p. (v letih 2006-2008 s 17 na 794 in 1.211):

\section{Graf 1: Število samoprijav 2006-2008 pri akontaciji dohodnine}

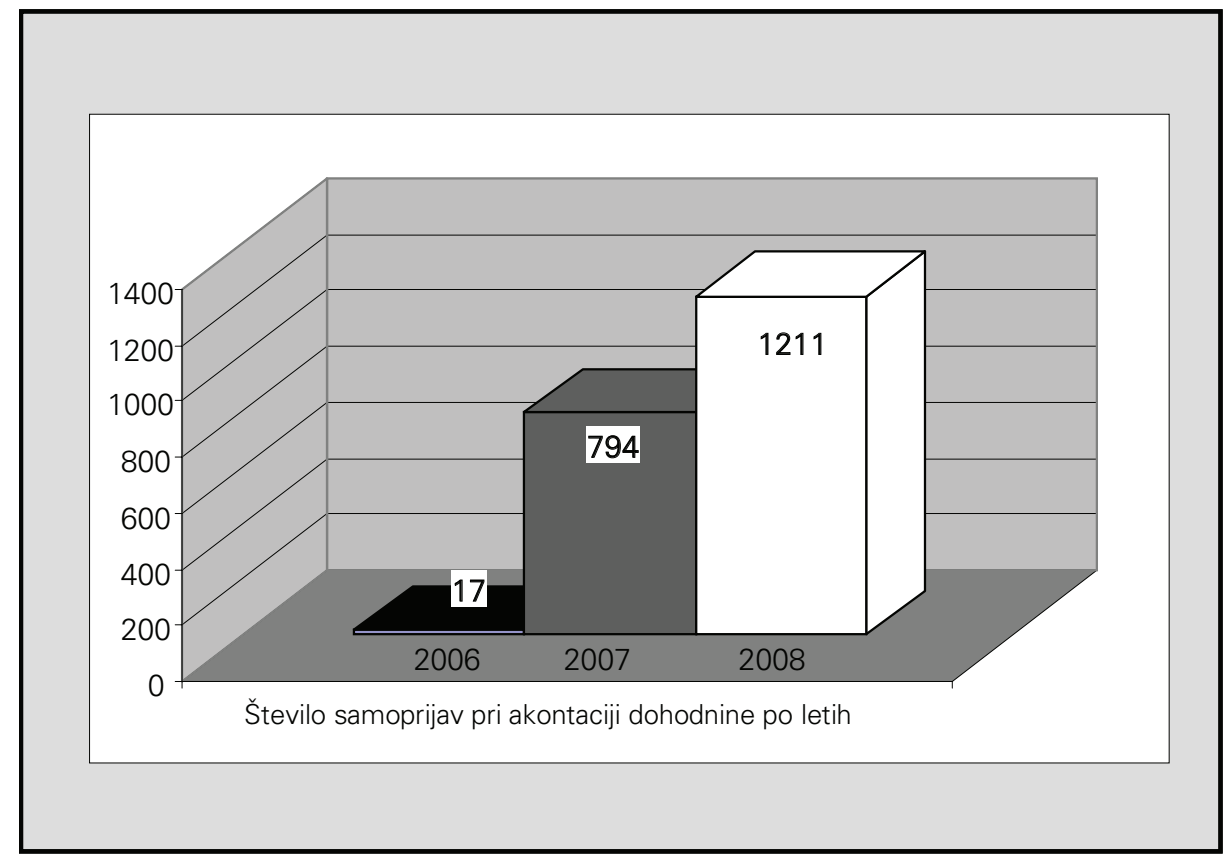

Po drugi strani pri določenih davkih število samoprijav upada, kar je pri dohodnini (za skoraj trikrat iz leta 2007 v 2008) zagotovo kombiniran rezultat uvedbe predhodne kontrole in informativnega izračuna kot predizpolnjene napovedi, podobno velja za druge dajatve. Glede na nove vire je očitno, da je v prihodnje 
pričakovati še nadaljnjo stabilizacijo števila in strukture samoprijav po vrstah davkov.

Sešteto so zavezanci zaradi samoprijav plačali $v$ treh letih skoraj 21 mio EUR. Tej vsoti bi bilo treba za izračun koristi instituta prišteti najmanj še stroške neuvedenih inšpekcijskih pregledov, zato kaže institut kot tak ohraniti, kvečjemu minorno nomotehnično izboljšati. Nemogoče pa je izmeriti pozitiven učinek stopnje večanja davčne kulture, ki se nedvomno prek prostovoljnega izpolnjevanja obveznosti občutno zvišuje.

\subsection{Navadno vročanje}

ZDavP-2 je v letu 2007 uvedel za razliko od 87. člena ZUP le navadno vročanje (glede na ZUP zaradi fikcije vročitve nekoliko prilagojeno) za večino pisanj $\vee$ davčnem postopku $z$ deklariranim ciljem prihranka stroškov davčnega organa za osebno vročanje. Kljub mogočim zadržkom o neustavnosti ureditve ZDavP-2 v razmerju do ZUP (o tem Kovač, 2008) so podatki za DURS tako vspodbudni, da potekajo v letu 2009 priprave na še večji obseg veljave določb o navadnem vročanju kot sedaj. ${ }^{14}$ Tako izračun datuma plačila $\vee$ grobem pomeni seštevek kronoloških dogodkov: odprava izvršilnega naslova, 20 dni za nastop fikcije vročitve in še 30 dni od vročitve za izvršljivost, torej plačilo davka (splošni paricijski rok). Povezano je treba upoštevati vrstni red poplačil (po vrstnem redu dospelosti za davke, navedene na plačilnem instrumentu). Fikcija vročitve je sicer pomembna enako kot za rok plačila in izvršbo za uveljavljanje pravnih sredstev, zato je DURS za bolj nesporen izračun datuma valute uvedla oznako datuma odprave na ovojnici (pri centralno tiskanih odločbah in odpremi $\checkmark$ tranšah natisne datum kar zunanji izvajalec).

Da ugotovimo prihranek iz naslova spremembe osebnega $\vee$ navadno vročanje, smo primerjali število izdanih odločb za dohodnino (prek 1,1 mio letno), nadomestilo za uporabo stavbnega zemljišča (cca 0,7 mio letno), davek od premoženja, davek iz premoženja, obresti, in kapital v letu 2006 pred uporabo ZDavP-2 in v letih 2007 in 2008. Število odločb je skoraj enako (dobre 2

14 Zakon določa: "Vse odločbe in sklepi ter drugi dokumenti, od katerih vročitve začne teči rok, razen odločb, sklepov in drugih dokumentov, ki se izdajo v postopku davčnega nadzora in v postopku davčne izvršbe, se vročajo z navadno vročitvijo. Šteje se, da je vročitev opravljena 20. dan od dneva odprave ..." Z ZDavP-2A je bila konec leta 2008 navadna vročitev nekoliko omejena, saj je bilo uvedeno obvezno osebno vročanje tudi za odločbe o obročnem plačilu davka, ne le za akte v nadzornih in izvršilnih postopkih. 
Polona Kovač

Zakon o davčnem postopku v okviru odprave

administrativnih ovir - med cilji in prakso

mio letno), razlika v stroških za vročanje pa na tej osnovi kar cca 2-3 mio EUR na letni osnovi:

Tabela 5: Stroški vročanja in prihranki zaradi navadnega vročanja 2006-2008

\begin{tabular}{|c|c|c|c|c|c|c|}
\hline 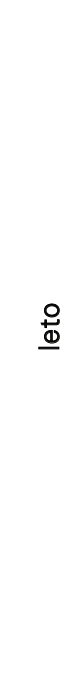 & 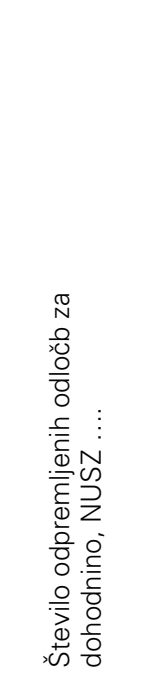 & 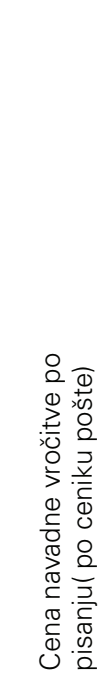 & 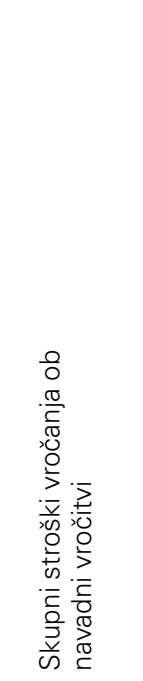 & 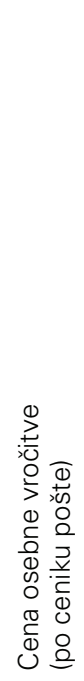 & 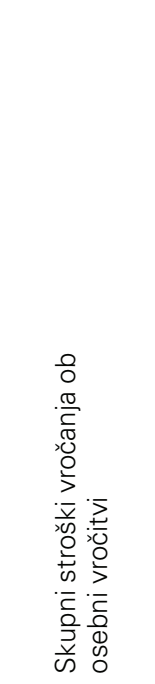 & 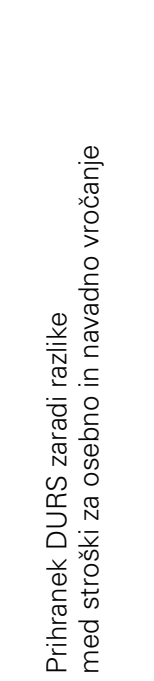 \\
\hline 2006 & $2,124,866$ & 0.24 & $509,967 *$ & 1.73 & $3,676,018$ & $3,166,051^{*}$ \\
\hline 2007 & $2,012,670$ & 0.25 & 503,167 & 1.78 & $3,582,552^{*}$ & $3,079,385$ \\
\hline 2008 & $2,013,327$ & 0.26 & 523,465 & 1.83 & $3,684,388^{*}$ & $3,160,923$ \\
\hline
\end{tabular}

*Izračun, kako bi bilo, če bi bila normativna ureditev nasprotna.

Te prihranke nekoliko zmanjšuje strošek posredovanja aktov, ki jih je vendar treba vročiti osebno po 85. členu ZDavP-2, ker zavezanec $v$ roku za plačilo po fiktivni vročitvi obveznosti ni poravnal (ali pisanja ni prejel ali pa si je zavestno tako podaljšal čas izpolnitve obveznosti brez sankcije). Podatki, koliko je tovrstnih zadev, se ne spremljajo, ocena po izkušnjah $\vee$ praksi se giblje med 5 do $10 \%$ zadev. OECD ugotavlja, da je zavezancev, ki so pri neizpolnjevanju obveznosti benevoletni, ok. 70 \% (na Danskem $67 \%$, po Klun, 2009), torej je nedvoumno, da je navedeni delež prihranka opazno manjši. O tem neposredno pričajo predvsem pristojni v izvršilnih zadevah, saj se je obseg izterjav izredno 
povečal v letu 2009 v primerjavi s predhodnimi leti, ko se izvršilni naslovi še niso vročali navadno (empirični podatki sicer še niso zbrani za letno osnovo). Kakorkoli, pri 2.013.327 izdanih odločbah za leto 2008 bi tako stroški vročanja znesli za navadno vročitev 523.465 EUR, dodatno pa še 1.105.317 EUR, torej skupaj (le?) 2.055.606 EUR. Kot vidimo, je vsota prihranka še vedno bistvena, sploh ker se s tem denarjem ne zajeda pobrani davek za stroške režije, $v$ primerjavi s stroški izvršilnih postopkov pa vendar prejkone primerjava koristi in stroškov pokaže negativen izid.

\subsection{Odpis, odlog oziroma obročno plačilo davka}

ZDavP-1B je v primerjavi z osnovnim besedilom zakona podaljšal obdobje odložitve oziroma obročnega plačevanja davka z enega na dve leti, pri čemer zakon dopušča diskrecijsko odpis, odlog ali obroke za fizične osebe zaradi ogroženosti preživljanja zavezanca in njegovih vzdrževanih družinskih članov in po drugi strani odlog oziroma obroke za pravne osebe oziroma s.p. ter druge fizične osebe kot nosilce dejavnosti iz razloga večje gospodarske škode, ki bi nastala zaradi plačila $v$ roku (Jerovšek et al., 2008). Odlog oziroma obroki pa ne morejo biti odobreni za akontacije, odtegljaj in določene davke, kar je sicer tehnično sporno, saj se mešata merili določitve izjem po vrstah davkov in načinih izpolnitve obveznosti (tako Kovač, 2006, podobno Hren, 2009, drugače Predlog ZDavP-2, 2006, str. 185). ZDavP-2 je nadalje prinesel pomembnejše novosti v smislu OAO, kot je poseben primer odloga oziroma obročnega plačila, če zavezanec predloži instrument zavarovanja oziroma dovoli vknjižbo zastavne pravice $v$ registru, vendar zaradi odsotnosti meril le do 12 mesecev (103. člen). Nadalje bo fizična oseba, ki ne opravlja dejavnosti, lahko brez presojanja pogojev in meril po 101. členu ZDavP-2 zaprosila za tri mesečne obroke brez zavarovanja. Za čas odloga oziroma obročnega plačila sicer tečejo obresti, a le po medbančni obrestni meri za ročnost enega leta s ciljem ohranjanja realne vrednosti dolga (Jerovšek in Kovač, 2008). Vse opisane spremembe naj bi prispevale $k$ večjemu izpolnjevanju obveznosti v skladu z načelom zakonitosti, kar naj bi vodilo tudi $\vee$ manj izvršilnih postopkov in predvsem manj negativnih posledic za življenje in poslovanje zavezancev. Podatki DURS za leta 2004-2008 te domneve ne potrjujejo, saj kljub ugodnejšim pogojem s spremembo zakonodaje $v$ obravnavanem obdobju iz posredovanih podatkov ni zaznati posebnega povečanja vlog zavezancev za odpis. 
Polona Kovač

Zakon o davčnem postopku v okviru odprave

administrativnih ovir - med cilji in prakso

Tabela 6: Število odpisov, odlogov in obročnih plačil 2004-2008

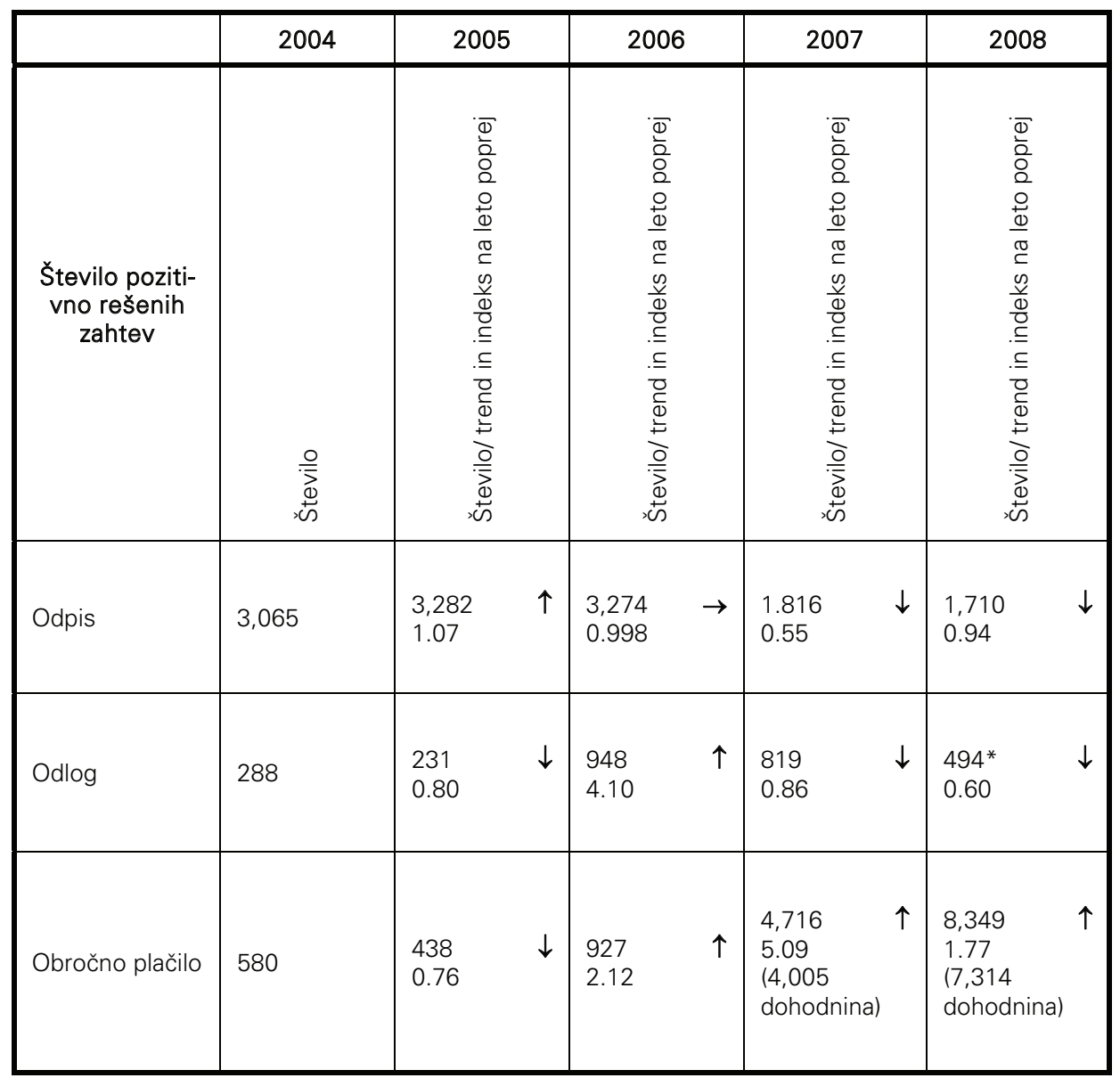

*Pozitivno rešenih 494 zahtev izmed skupaj 1181 vloženih. To pomeni cca 10 mio EUR (prim. z 1.120 mio EUR plačanega davka od dohodka v letu 2007, po Hren, 2009).

Iz tabele je razvidno, da je institut obročnega plačila med zadevnimi instituti najbolj aktualen, sploh $v$ letih 2007 in 2008, kar sovpada z gospodarsko krizo, (prim. graf 2), medtem ko odpis in odlog opazno upadata (z izrednim porastom odlogov in obročnih plačil leta 2006, ki jih kaže pripisati daljšemu obdobju po ZDavP-1B). Po vrstah davkov je v celotnem obdobju najbolj prisotna dohodnina (tudi socialni prispevki, davek od prometa proizvodov in storitev ter NUSZ). Dohodnina prevladuje predvsem pri odpisu (pravnim osebam ta praviloma ni dopusten) in pri obročnem plačilu $v$ zadnjih dveh letih od uporabe ZDavP-2. 


\section{Graf 2: Število odobrenih zahtev za obročno plačilo davka 2004-2008}

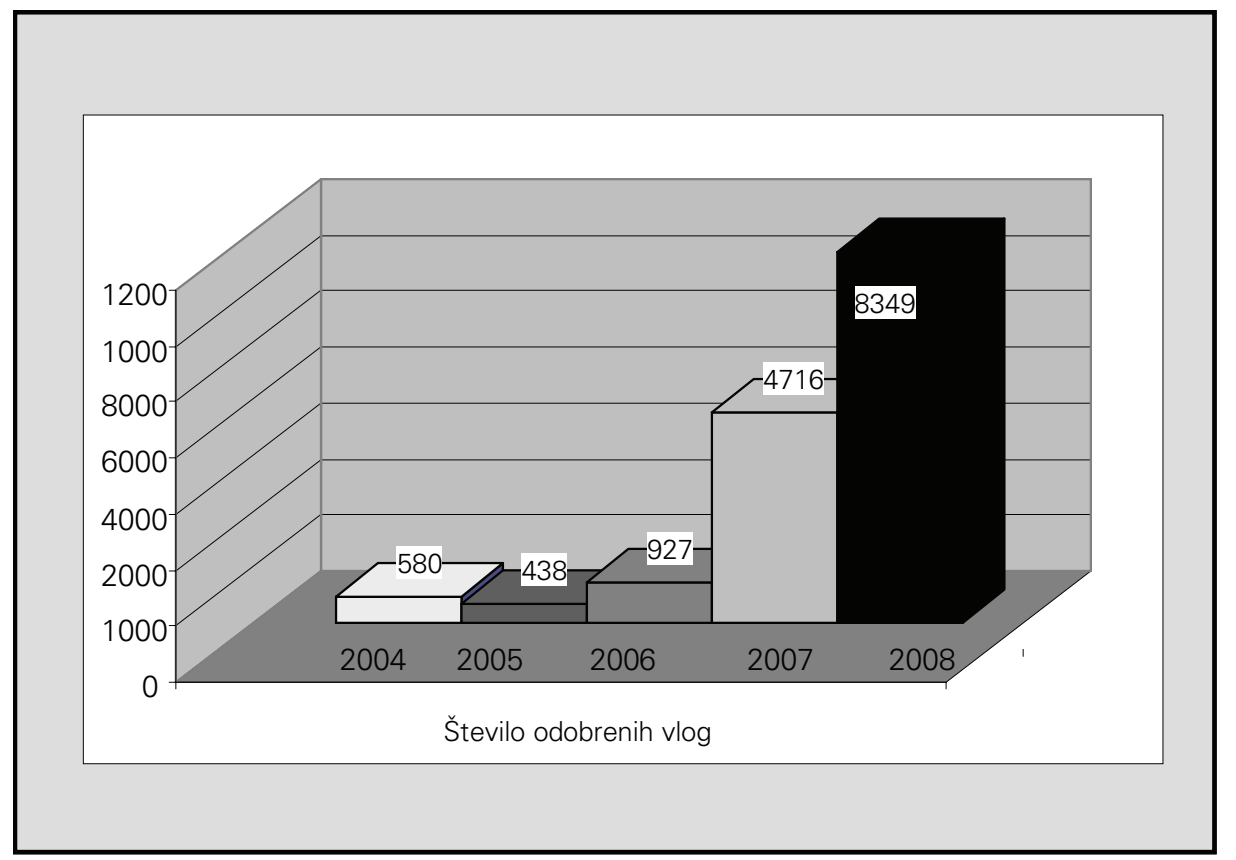

Porast obročnega plačevanja lahko brez dvoma pripišemo drugemu odstavku 103. člena ZDavP-2, ki se je izkazal kot izredno aktualen $v$ obstoječi družbeni situaciji. To velja za vse obravnavane institute $\vee$ luči iskanja skupnih interesov zavezancev (socialna zmožnost ob davčni obveznosti) in davčnega organa (prednost prostovoljne izpolnitve, da ni potreb po prisilnem nadzoru in izterjavi). Skupaj je bilo $v$ letu 2008 namreč odpisanih za cca 4,2 mio EUR davkov, odloženih za cca 10 mio EUR in določenih za obročno plačilo za kar približno 31,5 mio EUR (leto prej gre za cca 7 mio (odpis), 6 mio (odlog) in 17 mio (obroki) EUR). Ugotovimo lahko, da je zakonodajalec podal roko zavezancem (žal) glede na globalno krizo celo predčasno. To potrjujejo podatki za leto 2009 (skoraj $50 \%$ porast, $v$ le prvih dveh mesecih prejetih 1300 zahtev za obročno plačevanje $\vee$ primerjavi s cca 850 isto obdobje lani, po Hren, 2009). Ob pričakovani omilitvi krize bo institut še vedno potreben, zato naj se ohrani, morda celo poenostavi način uveljavljanja, če ne samih pogojev po 101. in 102. členu ZDavP-2.

Po uradni dolžnosti se meseca februarja od leta 2007 nadalje odpiše davčna obveznost po posamezni vrsti davka, ki konec koledarskega leta znaša manj kot 1 EUR (105. člen ZDavP-2), saj tako vrednost davka ne dosega niti $5 \%$ 
Polona Kovač

Zakon o davčnem postopku v okviru odprave administrativnih ovir - med cilji in prakso

povprečnih stroškov postopka izvršbe (prim. Jerovšek, 2005). Institut odpisa oziroma saldacije se kaže kot pozitiven tudi za preglednost davčnih evidenc, sploh upoštevaje objektivni element teže dolga (upoštevan $\vee$ ZDavP-2 npr. tudi pri določitvi zavezancev za nadzor, prim. Jerovšek et al., 2008). Slednje je očitno predvsem ob naslednjih podatkih v letih od 2006 do 2008:.

\section{Graf 3: Odpis davka po višini neplačanega dolga glede na status zavezancev 2006-2008}

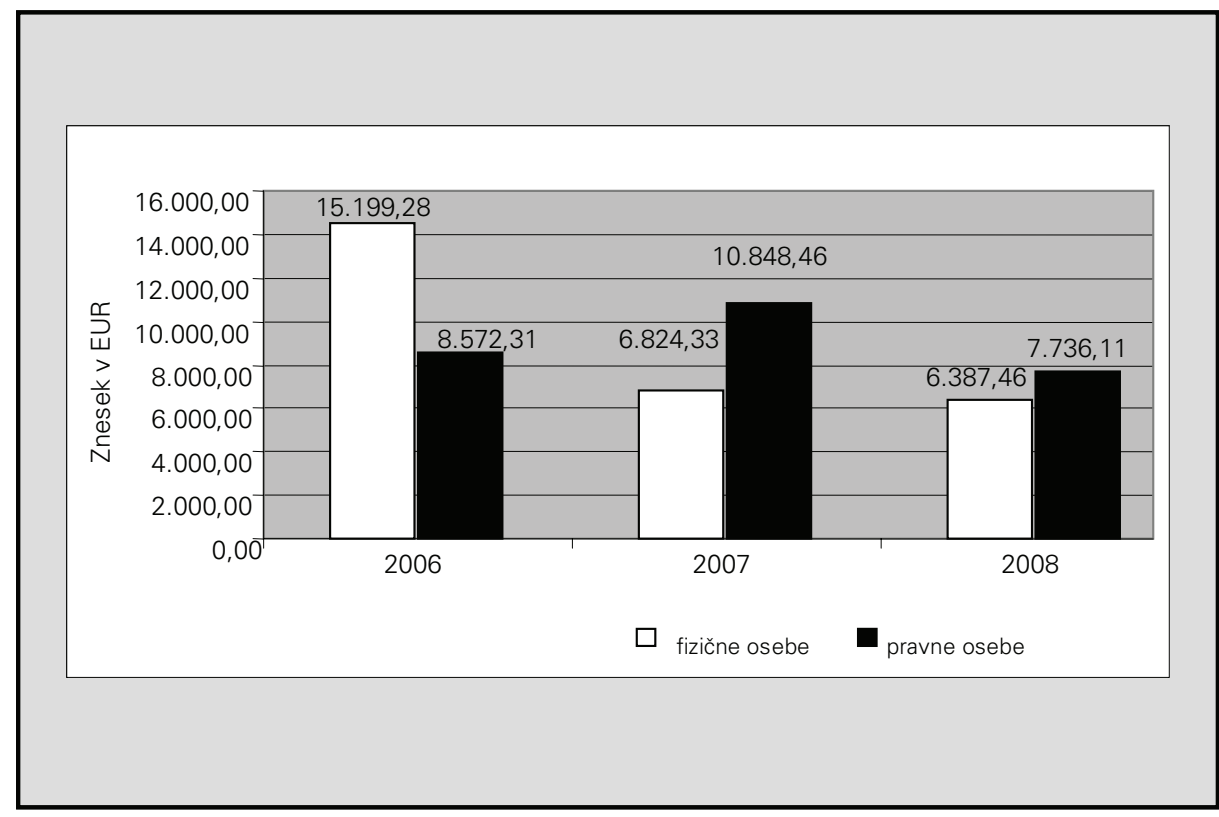

Z odpisovanjem $v$ plačilo dospelega bagatelnega zneska davka davčnemu organu ni treba voditi knjigovodstva za številne davčne zavezance, katerih dolg je $\vee$ predhodnem letu zapadel $\vee$ plačilo in ne preseže 1 EUR. Omenjeni institut nedvomno zasleduje ukrepe odprave administrativnih ovir predvsem za davčni organ in zavezance, čeprav določeno izgubo trpi skupni proračun. A ta izguba je $\checkmark$ primerjavi s stroški vodenja evidenc, postopkov odmer, nadzorov in zlasti izterjav zanemarljiva, zato je predmetni institut de lege ferenda (ob predhodnih izračunih posledic) smiselno prek dviga cenzusa do 10 EUR (glede na analogijo intra legem) celo še bolj aktualizirati, zlasti ker pomaga izrazito socialno šibkim zavezancem. 


\subsection{Davčna preiskava}

Davčna preiskava pomeni za zakon o davčnem postopku v letu 2007 nov institut (prej le v zakonu o davčni službi), s katerim se skuša davčnemu organu omogočiti nadzor nad praviloma večjimi nepravilnostmi oz. skupinami oseb, ki delujejo $v$ transnacionalnih strukturah (Predlog ZDavP-2, 2006, str. 190), torej ko metode klasičnega inšpekcijskega nadzora odpovedo. Gre za neke vrste predupravni postopek, kajti če se razlogi za sum izkažejo za utemeljene, se začne inšpekcijski postopek in dokazi iz preiskave se v tem postopku uporabijo, zato se OAO pri tem institutu kaže $v$ smeri večje učinkovitosti davčnega organa, nenazadnje pa zaščitenih poslovnih partnerjev obravnavanega zavezanca, sam zavezanec pa je varovan predvsem prek določb ZIN in ZUP (Androjna in Kerševan, 2006). Institut je lahko sistemsko sporen (Kovač, 2006). Kljub funkciji pregona se namreč zavezancu sklep o začetku in predmetu preiskave sploh ne vroči, ima le vlogo internega akta davčnega organa $v$ razmerju do inšpektorjapreiskovalca; zavezanec ima možnost izjaviti se (samo) ob uvedbi inšpekcijskega postopka (prim. Šinkovec, 2002).

Iz zbranih podatkov (graf 4) je razvidno, da se je institut $v$ praksi uveljavil že v letu 2007 (skupaj 358 prijav in 224 zaključenih inšpekcijskih pregledov na podlagi ugotovitev preiskav) in enako 2008 (397 prijav in 188 inšpekcijskih pregledov, tu manjši upad - indeks 0,84 glede na leto 2007). Po načinu prijave prevladuje delež anonimnih prijav, cca $60-70 \%{ }^{{ }^{15}}$

Po poročilu DURS za leto 2007 je bilo delovanje pristojnega preiskovalnoanalitskega oddelka usmerjeno predvsem $v$ odkrivanje davčnih goljufij s področja prometa z naftnimi derivati (odkritih 29 t. i. missing trade družb ${ }^{\mathbf{1 6}}$ in motornimi vozili (12 preiskav), posojilništva (15 preiskav) in gostinstva. Največkrat je prijavitelj fizična oseba, $v$ letu 2008 prevladuje kot zaposleni pri delodajalcu, ki ga prijavlja v zvezi z delom na črno (zlasti v gradbeništvu), dvigi gotovine odgovornih oseb pri pravnih osebah in neizdajanjem računov. Med prijavljenimi prevladujejo po pričakovanju glede na večjo vrednost dolgov po vrsti davkov pravne

15 Poleg teh prijav deluje od aprila 2007 24-urna brezplačna telefonska linija, prek katere ljudje precej vlagajo prijave (leta 2007 kar 606, leta 2008 še $23 \%$ več), a je uporabnih, ki bi vodile k pobranemu davku, komaj $12-15 \%$ (90 od 606 oziroma 93 od 744).

$16 \mathrm{~V}$ mesecu aprilu 2008 je zaživela za odkrivanje in pregon teh oseb aplikacija "Rdeča pika», ki je bila uvedena na podlagi ugotovitve, da se kot "missing trader-ji « pojavljajo vedno iste osebe. S pomočjo aplikacije delajo inšpektorji in preiskovalci ter referenti na področju registracije DDV; v sistem je bilo po poročilu DURS za leto 2008 na dan 30. 6. 2008 vnesenih 452 zavezancev. 
Polona Kovač

Zakon o davčnem postopku v okviru odprave

administrativnih ovir - med cilji in prakso

osebe, teh je bilo leta 2008 179, torej 45 \%, skupaj s s.p. kot gospodarskimi subjekti pa 73 \% (še 111 s.p. od skupaj 397 prijavljenih).

Graf 4: Število prijav za davčne preiskave po načinu prejema 2007 in 2008

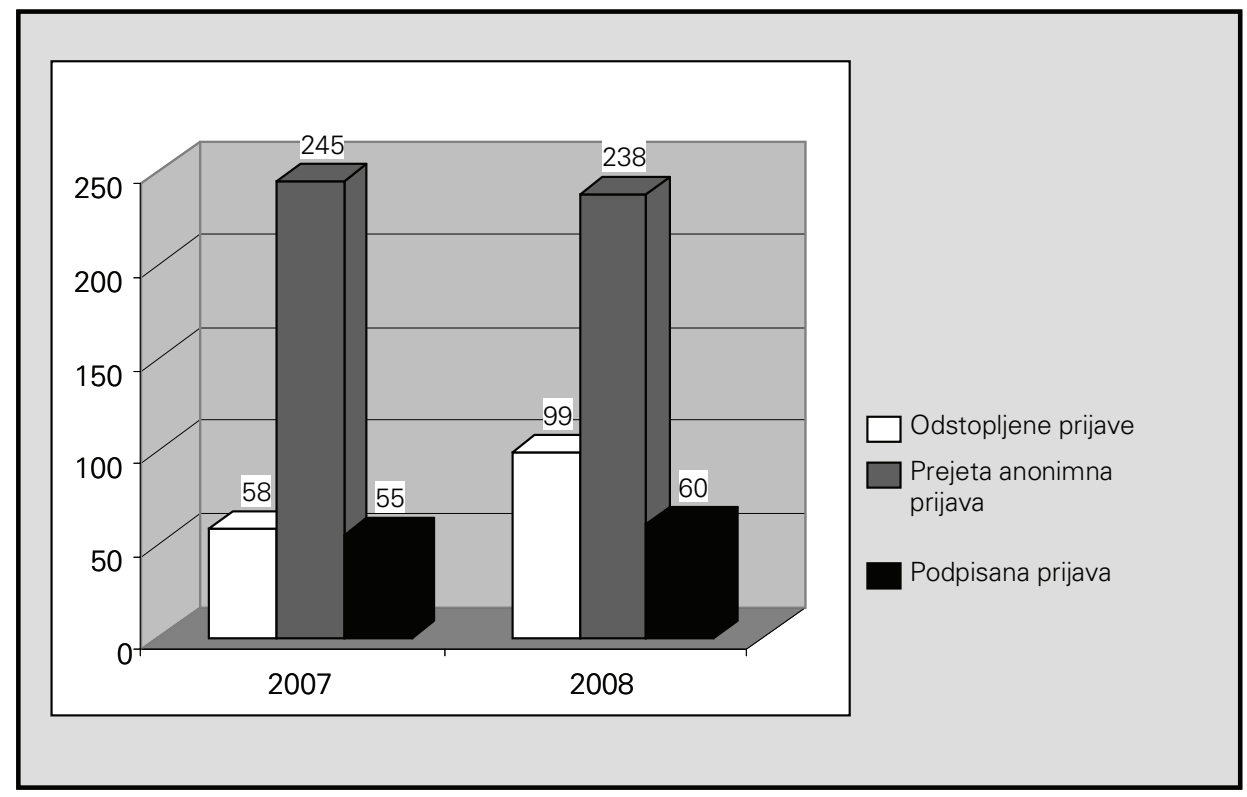

Skupni izplen zaključenih inšpekcijskih pregledov na podlagi preiskav je bil leta 2007 skoraj 18,5 mio EUR (skoraj 7 mio EUR DDV) in leta 2008 cca 9,28 mio EUR. Izračun pokaže, da je povprečni donos končanega inšpekcijskega postopka cca 67.300 EUR ( $v$ letu 2008 sicer upad na indeks 0,6 glede na leto poprej). Temu gre prišteti še prihodek proračuna zaradi določenih prekrškovnih glob.

\subsection{Obvestilo o neplačanem davku v izvršbi}

Zakonodajalec je s ciljem prijaznosti (o tem kritično Jerovšek, 2005) uvedel $\checkmark$ ZDavP-1 institut obvestila o neplačanem davku kot procesno predpostavko za začetek izvršbe. Dolžnik je imel od poziva (poslanega z osebno vročitvijo) 8 dnevni rok za plačilo dolga, da se izterjava ni uvedla. $\vee$ praksi je to pomenilo velik strošek za državo (tako zaradi administriranja kot nepriliva dolgovanih davkov, ker izvršba še ni bila niti začeta), zavezancu pa je omogočalo učinkovito 
zavlačevanje izvršbe (vse do 73 dni po izračunu Jerovška, prav tam). Zato je bil 128. člen že leta 2006 z novelo ZDavP-1B spremenjen in sicer se je $v$ sklopu OAO odpravila določba, ki je določala osebno vročanje obvestila.

ZDavP-2 je zaradi OAO $\vee$ celoti črtal določila o obvestilu o neplačanem davku, pri čemer se pojavlja vprašanje, ali je bil ta ukrep glede na pobrani znesek davkov na podlagi obvestil res (zgolj) administrativna ovira. Davčni organi ugotavljajo nasprotno, zato kljub neposredno neobstoječi pravni podlagi v ZDavP-2 zaradi $\vee$ praksi ugotovljenega deleža bolj ali manj benevolentnih zavezancev, ki morda zavlačujejo plačilo, ne pa za ceno izvršbe, še vedno pošiljajo dolžnikom obvestila, še sploh zaradi navadnega vročanja po 85. členu ZDavP-2. Pri tem so trendi rasti še bolj ugodni po znesku plačanega kot samem številu postopkov (podatki po letnih poročilih DURS). ${ }^{\mathbf{1 7}}$

Tabela 7: Število obvestil o neplačanem davku pred izvršbo in znesek plačil 2005-2008

\begin{tabular}{|c|c|c|c|c|c|c|c|}
\hline & 2005 & $\begin{array}{l}2006 / \text { trend na } \\
\text { leto poprej }\end{array}$ & & $\begin{array}{c}2007 \text { / trend } n \\
\text { leto poprej }\end{array}$ & & $\begin{array}{l}2008 \text { / trend } \\
\text { leto poprej }\end{array}$ & \\
\hline $\begin{array}{l}\text { Število } \\
\text { obvestil }\end{array}$ & 349,213 & $\begin{array}{l}437,355 \\
1.25\end{array}$ & $\uparrow$ & $\begin{array}{l}307,468 \\
0.70\end{array}$ & $\downarrow$ & $\begin{array}{l}333,473 \\
1.08\end{array}$ & $\uparrow$ \\
\hline $\begin{array}{l}\text { Znesek } \\
\text { plačanega po } \\
\text { obvestilu v } \\
\text { EUR }\end{array}$ & *705,846,269 & $\begin{array}{l}* 986,614,355 \\
1.40\end{array}$ & $\uparrow$ & $\begin{array}{l}570,252,913 \\
0.58\end{array}$ & $\downarrow$ & $\begin{array}{l}690,279,812 \\
1.21\end{array}$ & $\uparrow$ \\
\hline
\end{tabular}

*Temu znesku je treba odšteti stroške osebnega vročanja (v letu 2006 gre po tarifi 1,73 EUR na pošiljko za skupaj 651.659 EUR razlike med stroški osebnega in navadnega vročanja obvestil).

Primer obvestila o neplačanem dolgu je zanimiv, ker nam osvetli več razsežnosti normiranja davčnega postopka in delovanja DURS. Prvič, davčni

17 Dodatno je nekaj izplena iz naslova vrstnega reda poplačil, saj se zavezancem obračunava dolgove po datumu prispetja, za preostali dolg pa se ne vroča ponovno (osebno), ampak se zavezanca obvesti in pozove k plačilu. Če zavezanec po prejetem obvestilu davčnemu organu potrdi, da je odločbo prejel oziroma bo obveznost plačal, se šteje, da je odločbo prejel. $V$ prid ohranitve instituta govori tudi dejstvo, da je pošiljanje obvestila smotrno predvsem v primerih, ko gre za manjše davčne dolgove, saj bi uvedba takojšnje izvršbe za dolžnika pomenila dodatne stroške izterjave ( 20 evrov) in stroške banke (cca 35 evrov). 
Polona Kovač

Zakon o davčnem postopku v okviru odprave

administrativnih ovir - med cilji in prakso

organ lahko deluje sploh $v$ smislu varstva pravic zavezancev in ob hkratni neogroženosti javne koristi neposredno po temeljnih načelih, ne le na podlagi eksplicitnih pravil. Dalje, nekatera pravila, ki so se na prvi pogled, celo po enotnem mnenju stroke, kazala kot tipična administrativna ovira, prinašajo zelo koristne učinke že $\vee$ finančni izdatnosti, kaj šele $v$ zadovoljstvu $\vee$ postopek vpletenih udeležencev. Sprememba zakonodaje je tako v letih 2006 in 2007 vplivala predvsem na znižanje stroškov pošiljanja obvestil, ne pa na izumrtje instituta. Tretjič, vsako pravilo je treba pri izvajanju in ocenjevanju, ali gre za administrativno oviro, gledati ob součinkovanju celega zakona in načina dela organa.

\subsection{Informativni izračun pri odmeri dohodnine}

V okviru odprave administrativnih ovir naj bi v praktičnem smislu največji doprinos novega ZDavP-2 predstavljal princip odmere dohodnine prek predhodnega informativnega izračuna $z$ mešano naravo napovedi (ta kot predizpolnjena poslana po 421. členu ZDavP-2 že leta 2007 do 30. 4. 2007) in odločbe (od leta 2008 dalje), če ni vloženega ugovora (267. in nadaljnji členi ZDavP-2, (prim. Jerovšek, 2005a, Predlog ZDavP-2, 2006, str. 14). ZDavP-2 določa, da za dohodnino 2007 in nadaljnje, torej postopke od leta 2008 naprej, davčni organ s predhodno notranjo kontrolo na podlagi podatkov izplačevalcev oziroma registrov premoženja (ti pošljejo podatke do 31. 1. za preteklo leto) pripravi informativni izračun dohodnine do 31. 5., ki se šteje za napoved (zaradi zagotovitve skladnosti s splošnim delom zakona, predvsem pa prevzema odgovornosti zavezanca za resničnost, pravilnost in popolnost podatkov) in hkrati za osnutek odmerne odločbe, ki s potekom roka za ugovor, če ni vložen, postane izvršilni naslov. Če je vložen ugovor, se izda odmerna odločba do oktobra, prav tako odločba sledi vloženi napovedi do 30. 6. za preteklo leto, če zavezanec ni prejel informativnega izračuna, pa je stvarno legitimiran kot zavezanec.

Za leto 2007 je bilo vloženih le cca 34.000 napovedi neposredno od zavezancev, za leto 2008 pa 33.838 v primerjavi z 1.276 .860 v letu 2005 oziroma 1.135 .422 $\checkmark$ letu 2006 ( $v$ vseh teh letih pa DURS beleži skupno od cca 1,012 do 1,275 mio aktov s pravno naravo odločbe). Opisana rešitev prinaša koristi tako za zavezance, ki so praviloma odvezani priprave napovedi, če izplačevalci pošljejo DURS pravilne podatke, kot davčne organe, saj se je naknadna kontrola na prvi stopnji prevesila $\vee$ predhodno, a je bistveno manj ugovorov in zlasti pritožb (enako po podatkih OECD pri predizpolnjenih napovedih, Kovač, 2006a, Klun, 2009), rok plačila (ali vračila) pa prejkone bolj zgoden. O slednjem priča podatek, da je že 
pred iztekom roka za pripravo izračuna, konkretno na dan 6. 5. za dohodnino za prejšnje leto v letih 2008 in 2009 postalo izvršilni naslov kar prek 470.000 informativnih izračunov. Torej predvidoma cca $46 \%$ vseh dohodninskih zavezancev plača obveznost (oziroma prejme vračilo) že $v$ juniju, medtem ko so se prve odločbe $v$ letih 2005 in 2006 izdale konec maja ali še celo $v$ drugi polovici junija. Poleg navedenega je pomembno ugotoviti, da je DURS zaradi vnosa napovedi v ustrezne aplikacije in še naknadne kontrole vsako leto do leta 2006 zaposloval tudi študente, zato ob sedanji organizaciji dela ta dodatna organizacija in stroški v veliki meri odpadejo. Same uradne osebe na DURS se lahko (bolj) posvetijo vsebinskemu nadzoru na račun odpada operativnih vnosov. Dodatno so prihranki zaradi navadnega vročanja informativnih izračunov.

Glede na podatek letnega poročila DURS za leto 2007 je bil delež vloženih ugovorov zoper informativne izračune kar več kot tri četrtine, tj. 76,64 \%, v letu 2007 pretežno posledica »napak « zavezancev samih, ker niso pravočasno posredovali DURS podatka o vzdrževanih članih, da bi se olajšava obračunala po zahtevi staršev. Sicer je $\vee$ prvi tranši izdanih izračunov (oziroma leta 2007 predizpolnjenih napovedi), teh na dan 31. 3. prek pol milijona, ugovore vložilo v letu 2007 le 7,3 \%, leta 2008 pa celo (verjetno na osnovi izkušenj s prijavo vzdrževanih članov $v$ letu 2007) zgolj 4,3\% zavezancev (22.408 od skupaj 518.973). Trend je torej $v$ skladu s cilji instituta in opazno pozitiven po letih 2007-2008. Davčni organ se je izkazal kot učinkovit servis, sam institut predhodnega informativnega izračuna pa z nadgradnjo izvršilnega naslova in ne le pravno naravo predizpolnjene napovedi predstavlja slovensko regulacijo dohodninskega postopka kot eno najmodernejših in najučinkovitejših na svetu (prim. Kopp, 2003, Klun, 2009).

\section{Sklepi}

Sklepno lahko ugotovimo, da večina obravnavanih institutov, urejenih na novo s sklicem na program OAO v zakonu, ki ureja davčni postopek, od leta 2006 in 2007 naprej, dejansko dosega zastavljene cilje, torej poenostavljene postopke za zavezance in davčni organ. Navedeno je mogoče argumentirati s podatki o pogostnosti rabe institutov in izračuni prihrankov, vendar je treba dodati, da realizacija ciljev ne velja za vse institute. Tako na področju davčnega postopka kot širše pri normiranju v sklopu OAO se neredko le delno upošteva, da mora biti operacionalizacija načela usmerjenosti $k$ uporabniku zaradi načel ekonomičnosti in učinkovitosti javne uprave omejena z izkazanimi potrebami (in 


\section{Polona Kovač \\ Zakon o davčnem postopku v okviru odprave administrativnih ovir - med cilji in prakso}

ne le željami) strank in poprejšnjo diferencirano analizo zmožnosti organa oziroma javne uprave kot celote.

Še pomembnejše je spoznanje, da uporabljeni podatki niso edini relevantni za zbirno oceno. Posamična pravila predpisov učinkujejo namreč večplastno, isto- ali nasprotnosmerno, zato se predvideni pozitivni učinki lahko celo sinergično povečujejo (tako npr. pri navadnem vročanju informativnih izračunov) ali pa se izničijo. Celo nekatere odpravljene obveznosti udeležencev postopkov (npr. obveščanje dolžnikov pred uvedbo izvršbe) so zato vredne premisleka, ali jih ne bi zaradi ugotovljenih pozitivnih koristi znova vpeljali $\vee$ veljavno ureditev. Večino obravnavanih institutov, predvsem sistem obračunavanja dohodnine, navadno vročanje in posebne primere odpisa, odloga oziroma obročnega plačevanja davka, pa lahko ocenimo kot ustrezne družbeni realnosti in stremljenju k modernizaciji slovenske javne uprave.

Dr. Polona Kovač je zaključila doktorski študij I. 2005 na Pravni fakulteti v Ljubljani. V letu 2001 se je polno zaposlila na Fakulteti za upravo, kjer je danes kot docentka za področje javne uprave nosilka več predmetov na prvi in drugi stopnji, sodeluje pa tudi z več drugimi fakultetami. Vse od konca devetdesetih let stalno izvaja različne seminarje in delavnice ter predstavlja in objavlja prispevke na domačih in mednarodnih konferencah. Zadnja leta deluje tudi kot ocenjevalka in razsodnica $v$ okviru postopka podelitve Priznanja $R S$ za poslovno odličnost, evalvatorka $v$ postopkih evalvacije kakovosti visokošolskih programov oz. zavodov, članica senata Fakultete za upravo, članica vladnega strateškega sveta za javni sektor in predsednica Uradniškega sveta. 


\section{Literatura in viri:}

- $\quad$ Androjna, V., \& Kerševan, E. (2006). Upravno procesno pravo. Ljubljana: GV Založba.

- Davčna uprava Republike Slovenije. (b. d.). Pridobljeno 30. 9. 2009 s : http://www.durs.gov.si/

- Ferlinc, A. (2009). Razmerje med kazenskim in davčnim postopkom - privilegij zoper samoobtožbo. Ljubljana: Pravnik, letn. 64, št. 1-2, 25-56.

- Hren, B. (2009). Podjetja "zasula« Durs z vlogami za odlog plačila davkov. Dnevnik, 9. 4. 2009, 17.

- Jerovšek, T. (1999). Zakon o splošnem upravnem postopku (ZUP) z uvodnimi pojasnili. Ljubljana: Uradni list RS.

- Jerovšek, T. (2005). Kakšni inštituti lahko omogočijo hiter in učinkovit davčni postopek. XII. Dnevi slovenske uprave. Portorož (11 str.). Ljubljana: Fakulteta za upravo.

- Jerovšek, T. (2005a). Nekatere sugestije za drugačno ureditev davčnega postopka. Javna uprava (2/3), 286-299.

- Jerovšek, T., et al. (2008). Zakon o davčnem postopku s komentarjem. Ljubljana \& Maribor: Davčno izobraževalni inštitut \& Davčno finančni raziskovalni inštitut.

- Jerovšek. T., \& Kovač, P. (2008). Posebni upravni postopki Ljubljana: Fakulteta za upravo.

- Josevski, D. (2008). Slovenski program odprave administrativnih ovir s posebnim poudarkom na poenostavljanju upravnih postopkov. Podjetje in delo (6/7), 1339-1349.

- Klun, M. (2009). Pre-filled Income Tax Returns: Reducing Compliance Costs for Personal Income Tax Payers in Slovenia. Financ. theory pract., letn. 33, št. 2, 219-233.

- Kopp, F. O., \& Ramsauer, U. (2003). Verwaltungsverfahrensgesetz. Muenchen: Beck.

- Kovač, P. (2006). Nov koncept davčnega postopka - izbrana vprašanja. V: Vladne reforme in javni sektor ter predsedovanje Slovenije Evropski uniji (ur. Setnikar-Cankar, S.). Ljubljana: Fakulteta za upravo.

- Kovač, P. (2006a). Postopkovna vprašanja davčnega inšpekcijskega nadzora. Javna uprava (2/3), 273-296.

- Kovač, P. (2007). The development of tax procedures in Slovenia. V: Trends in development of public administration in South East Europe (ur. Vintar, M., Kovač, P.). Upravna misel. Ljubljana: Fakulteta za upravo \& NISPAcee, 153-172.

- Kovač, P. (2008). Vročanje v upravnem postopku (od vročitve upravne odločbe do njene izvršitve). Podjetje in delo (6/7), 1302-1316.

- $\quad$ Pirnat, R. (gl. ur.), et al. (2004). Komentar zakonov s področja uprave ŠZJU, ZDU-1, ZSPJS, ZJA, ZINĆ. Ljubljana: Inštitut za javno upravo pri Pravni fakulteti Univerze v Ljubljani. 
Polona Kovač

Zakon o davčnem postopku v okviru odprave administrativnih ovir - med cilji in prakso

- $\quad$ Predlog Zakona o davčnem postopku (ZDavP-2). Poročevalec DZ RS, št. 99/06 (20. 9. 2006).

- $\quad$ Predlog zakona o spremembah in dopolnitvah zakona o davčnem postopku (ZDavP-2A). Poročevalec DZ RS, št. $127 / 08$ (19. 12. 2008).

- Silvani, C., \& Baer, C. (1997). Designing a Tax Administration Reform Strategy, Experiences and Guidelines. IMF Working Paper, WP/97/30. Washington: IMF.

- Šinkovec, J., \& Tratar, B. (2002). Zakon o davčnem postopku s komentarjem. Lesce: Oziris.

- Šturm, L. (ur.), et al. (2002). Komentar Ustave Republike Slovenije. Brdo: Fakulteta za podiplomske državne in evropske študije.

- Vlada Republike Slovenije: Program reform za izvajanje lizbonske strategije $v$ Sloveniji. Oktober 2008. Pridobljeno 30. 9. 2009 s:

http://www.svr.gov.si/fileadmin/srs.gov.si/pageuploads/Dokumenti/SI-NRP2008-slo.pdf 